Ewa JURGA-WOSIK

Uniwersytet im. Adama Mickiewicza, Poznań

\title{
Służba cywilna w Polsce. Kierunki zmian
}

W Polsce służba cywilna charakteryzuje się brakiem ciągłości prawno-instytucjonalnej. W ciagu ostatnich dwunastu lat uchwalono cztery ustawy o służbie cywilnej. Akty te w różny sposób regulowały m.in. kwestie organu właściwego w sprawach służby cywilnej (Szef Służby Cywilnej lub Szef Kancelarii Prezesa Rady Ministrów) i jego obsługi (Urząd Służby Cywilnej Kancelarii Prezesa Rady Ministrów) czy kwestie statusu wyższych stanowisk (w służbie cywilnej i poza nią) oraz sposobu ich obsadzania (konkursy, powołania/mianowania, nabór). Natomiast sama idea służby cywilnej narodziła się we Francji w okresie III Republiki. W literaturze przedmiotu wyróżnia się trzy modele zatrudnienia w służbie cywilnej - model kariery, model stanowisk (pozycyjny) oraz model mieszany, występujący najczęściej w praktyce ${ }^{1}$. Przyjęcie określonego modelu jest ściśle związane z tradycją narodową w danym kraju oraz z definicją i rolą państwa w jego stosunkach ze społeczeństwem. Polski model służby cywilnej można określić jako mieszany z przewagą uregulowań właściwych dla modelu kariery. W modelu kariery podmiotem zatrudniającym urzędnika jest państwo. Urzędnik jest przyjmowany do korpusu służby cywilnej albo do jednej z kategorii tego korpusu (na najniższe stanowisko), a nie na konkretne stanowisko. Jego stosunek zatrudnienia jest bardzo stabilny - trwa, aż do przejścia urzędnika na emeryturę. W tym czasie realizuje się on w kolejno występujących po sobie stopniach kariery. Państwo gwarantuje urzędnikowi precyzyjnie uregulowane uposażenie i emeryturę lub rentę. Takie rozwiązania zbliżone występują we Francji, Niemczech, Austrii i zostały zmodyfikowane na rzecz specyfiki funkcjonowania urzędników w instytucjach Unii Europejskiej (tzw. model kariery zamknięty) ${ }^{2}$. W modelu stanowisk, podmiotem zatrudnia-

1 J. Czaputowicz, Stużba cywilna w procesie integracji europejskiej, w: Administracja publiczna. Wyzwania $w$ dobie integracji europejskiej, pod. red. J. Czaputowicz, Warszawa 2008, s. 272-274.

2 M. Małecki, K. Tomaszewski, Status urzędnika Unii Europejskiej, Warszawa 2005, s. 15 . 
jącym urzędnika jest konkretny urząd, a nie państwo jako całość. Jest on zatrudniany na konkretnym stanowisku, a nie w korpusie cywilnym „w ogóle”. Słabsza jest stabilność stosunku pracy oraz gwarancje wynagrodzenia. Rozwiązania bliskie temu modelowi występują m.in. w Wielkiej Brytanii, krajach skandynawskich i we Włoszech.

W Polsce służba cywilna pojawiła się w II Rzeczpospolitej, w ustawie z dnia 17 lutego 1922 r. o państwowej służbie cywilnej (Dz. U. Nr 21, poz.164), nowelizowanej kilkanaście razy przed wojną i po drugiej wojnie światowej (tekst jedn. Dz. U. 1949, Nr 11, poz. 72) 3 $^{3}$ Ustawa po wielu nowelizacjach przetrwała do 31 grudnia 1974 roku, a formalnie została uchylona przez ustawę z dnia 26 czerwca 1974 r. - przepisy wprowadzające Kodeks pracy (Dz. U. 1974, Nr 24, poz. 142). Służba cywilna w Polsce była również unormowana w następujących ustawach: z dnia 16 września 1982 r. o pracownikach urzędów państwowych (tekst jedn. Dz. U. 2001, Nr 86, poz. 953 ze zm.); z dnia 18 grudnia 1998 r. o służbie cywilnej (Dz. U. 1999, Nr 49, poz. 483), z dnia 5 lipca 1996 r. ustawa o służbie cywilnej (Dz. U. 1996, Nr 88, poz. 402 ze zm.) oraz z dnia 24 sierpnia 2006 r. (Dz. U. 2006, Nr 170, poz. 1218, ze zm.). Od 24 marca 2009 roku obowiązuje ustawa z dnia 21 listopada 2008 r. o służbie cywilnej (Dz. U. 2008, Nr 227, poz. 12610). Uchyliła ona ustawę z 24 sierpnia 2006 r. o służbie cywilnej oraz ustawę z 24 sierpnia 2006 r. o państwowym zasobie kadrowym i wysokich stanowiskach państwowych (Dz. U. Nr 170, poz. 217). Innymi aktami dotyczącymi służby cywilnej w Polsce są m.in. - zarządzenie Prezesa Rady Ministrów z dnia 13 lutego 2008 r. w sprawie zasad dokonywanych opisów i wartościowania stanowisk pracy w służbie cywilnej (M.P. 2008, Nr 15, poz.163 ze zm.), rozporządzenie Prezesa Rady Ministrów z dnia 21 grudnia 2006 r. w sprawie postępowania wyjaśniającego i postępowania dyscyplinarnego w służbie cywilnej (Dz. U. 2006, Nr 246, poz. 1798), rozporządzenie Prezesa Rady Ministrów z dnia 16 grudnia 2009 r. w sprawie sposobu przeprowadzenia postępowania kwalifikacyjnego w służbie cywilnej (Dz. U. 2009, Nr 218, poz. 1695.), rozporządzenie Prezesa Rady Ministrów z dnia 9 grudnia 2009 r. w sprawie

3 ABC stużby cywilnej, pod red. W. Drobnego, M. Mazuryka, P. Zuzankiewicza, Warszawa 2010, s. 23. Ustawa obejmowała nie tylko urzędników i niższych funkcjonariuszy państwowych (np. woźnych), zatrudnionych w administracji rządowej, lecz także urzędników zatrudnionych w innych urzędach państwowych, w szczególności w Kancelariach Sejmu i Senatu, Cywilnej Kancelarii Prezydenta RP oraz w Najwyższej Izbie Kontroli. 
określenia stanowisk urzędniczych, wymaganych kwalifikacji zawodowych, stopni służbowych urzędników służby cywilnej, mnożników do ustalenia wynagrodzenia oraz szczegółowych zasad ustalania i wypłacania innych świadczeń przysługującym członkom korpusu służby cywilnej (Dz. U. 2009, Nr 211, poz. 1630) oraz rozporządzenie Prezesa Rady Ministrów z dnia 8 maja 2009 r. w sprawie warunków i sposobu przeprowadzania ocen okresowych członków korpusu służby cywilnej (Dz. U. 2009, Nr 74, poz. 633).

Celem utworzenia korpusu służby cywilnej w Polsce jest wykształcenie profesjonalnej, rzetelnej, politycznie neutralnej i bezstronnej grupy urzędniczej (art. 1, ustawa o służbie cywilnej z dnia 21 listopada 2008 r.). Reguła ta przyświeca również funkcjonowaniu administracji instytucji europejskich, choć w praktyce - tak jak w Polsce nie zawsze jest respektowana ${ }^{4}$. Urzędnicy wchodzący w skład korpusu służby cywilnej podlegają ograniczeniom w celu zapewnienia neutralnego politycznie i bezstronnego wykonywania przez nich zadań państwa czy instytucji UE5 .

Ustawa o służbie cywilnej w Polsce z 2008 r. wprowadziła przede wszystkim zmiany polegające na ujednoliceniu ustawodawstwa regulującego zagadnienia kadrowe w administracji rządowej, a w szczególności objęła nowelizacją takie kwestie jak - organizacja służby cywilnej, nabór do służby cywilnej, pierwsza ocena służby cywilnej, postępowanie kwalifikacyjne i mianowanie w służbie cywilnej, obsadzanie wyższych stanowisk w służbie cywilnej, ocena okresowa członków korpusu służby cywilnej, szkolenia i rozwój służby cywilnej oraz strategia zarządzania zasobami ludzkimi w służbie cywilnej ${ }^{6}$. Ustawa przywróciła stan prawny

4 J. Czaputowicz, Stużba cywilna w procesie integracji europejskiej, w: Administracja publiczna. Wyzwania $w$ dobie integracji europejskiej, pod. red. J. Czaputowicz, Warszawa 2008, s. 275-276; M. Droba, Podstawy prawa, Warszawa 2008, s. 166; G. Krawiec, Europejskie prawo administracyjne, Warszawa 2009, s. 118; P. Tosiek, Komitologia. Szczególny rodzaj decydowania politycznego w Unii Europejskiej, Lublin 2007, s. 264-268; K. M. Witkowska-Chrzczonowicz, Pozycja prawna Komisji Europejskiej w systemie instytucjonalnym Wspólnot Europejskich, Toruń 2008, s. 229; http://ombudsman.europa.eu/report07/pdf/pl/short07_pl.pdf, odczyt 2008. Komunikat wiceprzewodniczącego Komisji Europejskiej, Neila Kinnocka w sprawie naboru urzędników z nowych państw członkowskich, przyjęty przez Komisję Europejską 18 lutego 2003 r., Bruksela 2003.

5 Konstytucja RP z 2 kwietnia 1997 r., art. 153 ust. 1; Rozporządzenie w sprawie kadr urzędniczych Wspólnot Europejskich i rozporządzenie w sprawie warunków zatrudnienia innych pracowników Wspólnot Europejskich, Tytuł II, art. 11-26a.

${ }^{6}$ ABC stużby cywilnej, op. cit., s. 55; http://www.dsc.kprm.gov.pl/aktualnosci.php?id=9\&look=212, odczyt 2009 r. 
sprzed 27 października 2006 roku, kiedy to w administracji rządowej odróżniane były dwa poziomy stanowisk - poziom polityczny obejmujący kierownicze stanowiska państwowe (ministrowie, sekretarze, podsekretarze stanu, wojewodowie, wicewojewodowie) i członków tzw. gabinetów politycznych oraz poziom służby cywilnej - stanowiska urzędnicze różnych szczebli administracji rządowej. Ustawa również uporządkowała tzw. poziom pośredni, czyli wysokie stanowiska państwowe, do których zaliczano m.in. stanowiska kierowników urzędów centralnych i ich zastępców, prezesów agencji państwowych i państwowych funduszy celowych oraz ich zastępców, dyrektorów generalnych ministerstw, urzędów centralnych i urzędów wojewódzkich, dyrektorów i zastępców dyrektorów departamentów w ministerstwach i urzędach centralnych oraz dyrektorów i zastępców dyrektorów wydziałów w urzędach wojewódzkich, a także wojewódzkich lekarzy weterynarii i ich zastępców. Wejściu nowej ustawy z 2008 r. towarzyszyło włączenie większości obecnych wysokich stanowisk państwowych (stanowiska dyrektorskie w urzędach administracji rządowej oraz stanowiska wojewódzkich lekarzy weterynarii i ich zastępców) do systemu służby cywilnej jako tzw. wyższe stanowiska w służbie cywilnej. Likwidacji uległ Państwowy Zasób Kadrowy (PZK). Jednak członkowie PZK, którzy weszli do niego, dzięki zdaniu egzaminu lub wygraniu konkursu na wysokie stanowisko państwowe, bądź też w latach 2007-2009 przeszli postępowanie kwalifikacyjne w służbie cywilnej z wynikiem uprawniającym do mianowania, to przez okres 10 lat zwolnieni są z obowiązku poddania się sprawdzianowi kompetencji kierowniczych, w przypadku ubiegania się o wyższe stanowisko w służbie cywilnej.

Najwyższym w hierarchii urzędu stanowiskiem w korpusie służby cywilnej jest stanowisko dyrektora generalnego, utworzone w Kancelarii Prezesa Rady Ministrów, w urzędzie ministra, urzędzie przewodniczącego komitetu wchodzącego w skład Rady Ministrów, urzędzie centralnego organu administracji rządowej oraz w urzędzie wojewódzkim (art. 25, ustawa o s.c.). Nie jest tworzone w Komendzie Głównej Policji, Komendzie Głównej Państwowej Straży Pożarnej oraz Komendzie Głównej Straży Granicznej. Natomiast w tych urzędach, w których stanowiska dyrektorów generalnych nie będą utworzone, ich zadania wykonywać będą - tak jak dotychczas - kierownicy urzędów. Dyrektor generalny podlega bezpośrednio kierownikowi urzędu. Zgodnie z ustawą z 2008 r. wyższymi stanowiskami obsadzanymi w drodze otwartego i konkurencyjnego naboru (art. 54) bądź w drodze przeniesienia (art. 54 ust. 2) są stanowiska dyrektora generalnego urzędu; kierującego departamentem lub komórką ró- 
wnorzędną w Kancelarii Prezesa Rady Ministrów, urzędzie ministra, urzędzie obsługującym przewodniczącego komitetu wchodzącego w skład Rady Ministrów, urzędzie centralnego organu administracji rządowej oraz kierującego wydziałem lub komórką równorzędną w urzędzie wojewódzkim, a także zastępcy tych osób; wojewódzkiego lekarza weterynarii i jego zastępcy; kierującego komórką organizacyjną w Urzędzie Rejestracji Produktów Leczniczych, Wyrobów Medycznych i Produktów Biobójczych oraz w Biurze Nasiennictwa Leśnego oraz zastępcy tych osób (art. 52). W przypadku obsadzania stanowisk zastępców dyrektorów departamentów w KPRM, ministerstwach i urzędach centralnych, zastępców dyrektorów wydziałów w urzędach wojewódzkich, zastępców wojewódzkich lekarzy weterynarii, a także zastępców kierowników komórek organizacyjnych w Urzędzie Rejestracji Produktów Leczniczych, Wyrobów Medycznych i Produktów Biobójczych oraz w Biurze Nasiennictwa Leśnego, możliwe będzie odstapienie od przeprowadzania otwartego naboru i przeniesienie na takie stanowisko członka korpusu służby cywilnej, który spełnia wymagania na to stanowisko i uzyskał ostatnią ocenę okresową na jednym z dwóch najwyższych poziomów w skali ocen. Rozwiązania administracyjne w Polsce są bliskie standardom europejskim. W instytucjach Unii Europejskiej dyrektorzy i dyrektorzy generalni, którzy na swoje stanowiska są mianowani, choć pochodzić też mogą z naboru otwartego i konkurencyjnego stanowią również wierzchołek władzy administracyjnej w korpusie służby cywilnej. Pomimo swojej niezależności, nie działają w oderwaniu od ogólnych wskazówek administracyjno-politycznych, choć dyrekcje generalne w opinii ekspertów cieszą się swojego rodzaju autonomią ${ }^{7}$ Przykładem może być administracja w Komisji Europejskiej. W rezultacie kontrolę nad poszczególnymi dyrekcjami generalnymi (hierarchicznie zbudowanymi na wzór ministerstw) sprawują z jednej strony - odpowiedni komisarze (czynnik polityczny), z drugiej - Sekretarz Generalny (czynnik administracyjny). W Polsce mamy podobne rozwiązania. Ustawa z 2008 r. przywraca Szefa Służby Cywilnej, jako centralny organ administracji rządowej właściwy w sprawach służby cywilnej (art. 10). Merytoryczną oraz organizacyjno-logistyczną obsługę tego organu zapewnia Kancelaria Prezesa Rady Ministrów. Szefa Służby Cywilnej powołuje Prezes Rady Ministrów, po zasięgnięciu opinii Rady

R. Herbut, Proces podejmowania decyzji w Unii Europejskiej - rola Komisji Europejskiej, w: Administracja i Polityka. Proces decyzyjny w administracji publicz$n e j$, pod red. L. Habudy, Wrocław 2000, s. 105-106. 
Służby Cywilnej. Pierwszym Szefem Służby Cywilnej na podstawie ustawy z 2008 r. został Sławomir Brodziński ${ }^{8}$. Kolejnym nowym organem jest powołana w miejsce dotychczasowej Rady Służby Publicznej - Rada Służby Cywilnej. Jest to organ opiniodawczo-doradczy Prezesa Rady Ministrów, liczący 15 członków (art. 19). Prezes powołuje osiem osób posiadających autorytet, wiedzę i doświadczenie, a pozostałych siedem - na wniosek klubów parlamentarnych, spośród posłów, senatorów lub osób nie będących parlamentarzystami. Przewodniczącym Rady Służby Cywilnej jest obecnie Adam Leszkiewicz?

O wyższe stanowisko w służbie cywilnej może ubiegać się osoba, która posiada tytuł magistra lub równorzędny, nie była karana zakazem zajmowania stanowisk kierowniczych w urzędach organów władzy publicznej lub pełnienia funkcji związanych $z$ dysponowaniem środkami publicznymi oraz posiada kompetencje kierownicze (art. 53). Podobnie jak wskazują procedury wyboru kandydata na dyrektora generalnego w strukturach Komisji Europejskiej, w Polsce brany jest również pod uwagę staż pracy - co najmniej 6 lat w tym 3 na stanowisku kierowniczym w jednostkach sektora finansów publicznych (w KE - 12 lat pracy, w tym 6 na stanowisku kierowniczym). Natomiast kandydat ubiegający się o inne wyższe stanowisko (nie dyrektora generalnego urzędu) - 3-letnim stażem pracy, w tym co najmniej rocznym stażem na stanowiskach kierowniczych lub co najmniej dwuletnim - na stanowiskach samodzielnych w jednostkach sektora finansów publicznych. Poza tym, tak jak w przypadku przyszłych urzędników unijnych - kandydat na wyższe stanowisko musi spełniać wymogi wynikające $\mathrm{z}$ opisu stanowiska pracy oraz z odrębnych przepisów prawa. Osoby zajmujące wyższe stanowiska w służbie cywilnej nie mogą pełnić funkcji w związkach zawodowych, tworzyć partii politycznych i w nich uczestniczyć, także - podejmować dodatkowych zajęć zarobkowych bez pisemnej zgody dyrektora generalnego urzędu, w którym są zatrudnione (art.78). Z kolei dyrektorom generalnym takiej zgody udzielać będzie Szef Służby Cywilnej po zapoznaniu się z pisemną opinią kierownika danego urzędu.

Korpus służby cywilnej składa się z pracowników służby cywilnej, czyli osób zatrudnionych na podstawie umowy o pracę oraz urzędników służby cywilnej, którzy zatrudnieni są na podstawie mianowania, po prze-

8 http;//wiadomości.onet.pl/1952708,11,item.html, odczyt 15.04. 2009 r.

9 http://www.dsc.kprm.gov.pl/aktualnosci.php?id=9\&look=217, odczyt 2.04 .2009 r. 
prowadzeniu postępowania kwalifikacyjnego i spełnieniu odpowiednich warunków (art. 3). W skład korpusu służby cywilnej wchodzą - pracownicy zatrudnieni na stanowiskach urzędniczych w: Kancelarii Prezesa Rady Ministrów; urzędach ministrów i przewodniczących komitetów wchodzących w skład Rady Ministrów oraz urzędach centralnych organów administracji rządowej; urzędach wojewódzkich oraz innych urzędach stanowiących aparat pomocniczych terenowych organów administracji rządowej podległych ministrom lub centralnym organom administracji rządowej; komendach, inspektoratach i innych jednostkach organizacyjnych stanowiących aparat pomocniczy kierowników zespolonych służb, inspekcji i straży wojewódzkich oraz kierowników powiatowych służb, inspekcji i straży - chyba że odrębne przepisy stanowią inaczej; Urzędzie Rejestracji Produktów Leczniczych, Wyrobów Medycznych i Produktów Biobójczych, Biurze Nasiennictwa Leśnego oraz korpus służby cywilnej tworzą także - powiatowi i graniczni lekarze weterynarii i ich zastępcy (art. 2). Stanowiska urzędnicze w urzędach mogą zajmować także osoby oddelegowane na podstawie odrębnych przepisów do wykonywania zadań poza jednostką organizacyjna, w której są zatrudnione. Z kolei prawa i obowiązki członków korpusu służby zagranicznej, a także zasady organizacji i funkcjonowania tej służby określają przepisy o służbie zagranicznej. A zatem korpus służby cywilnej tworzą pracownicy zatrudniani na stanowiskach urzędniczych - wyższych stanowiskach w służbie cywilnej, stanowiskach średniego szczebla zarządzania, stanowiskach koordynujących, samodzielnych, specjalistycznych oraz wspomagających. Pracownikiem służby cywilnej może zostać osoba będąca obywatelem polskim (z zastrzeżeniem art. 5), korzystająca z pełni praw publicznych, nie skazana prawomocnym wyrokiem za przestępstwo umyślne lub umyślne przestępstwo skarbowe, posiadająca wymagane kwalifikacje na dane stanowisko pracy i ciesząca się nieposzlakowaną opinią (art. 4). Nowa ustawa o służbie cywilnej nie wprowadza radykalnych zmian w zakresie naboru do służby cywilnej. Najistotniejsza zmiana dotyczy możliwości zatrudniania osób nie tylko posiadających obywatelstwo polskie, a także - obywateli państw Unii Europejskiej oraz innych państw, których obywatele mają prawo zatrudnienia na terenie RP (art. 5). Jednak osoby nie posiadające obywatelstwa polskiego, nie będą mogły zajmować stanowisk związanych $-\mathrm{z}$ bezpośrednim lub pośrednim wykonywaniem władzy publicznej ani ochroną generalnych interesów państwa. Nabór kandydatów do korpusu służby cywilnej organizuje dyrektor generalny, a dotyczy to także absolwentów Krajowej Szkoły Administracji Publicznej (art. 26). 
Natomiast Główny Lekarz Weterynarii organizuje nabór na stanowisko granicznego lekarza weterynarii i jego zastępcy, a wojewódzki lekarz weterynarii organizuje nabór na stanowiska powiatowego lekarza weterynarii i jego zastępcy (art. 27). Wzmocnieniu natomiast uległa zasada jawności, otwartości i konkurencyjności naboru. Do obecnie obowiązujących sposobów upowszechniania informacji o wolnych stanowiskach pracy - ogłoszenie w siedzibie urzędu i w BIP KPRM, dodano ogłoszenie na stronie podmiotowej BIP urzędu („Biuletyn urzędu”), który poszukuje pracowników (art. 28). W dalszym ciągu obowiązuje zasada, że informacja o przebiegu naboru jest informacją publiczną, choć zmodyfikowano sposób jej upowszechniania. Do niedawna upowszechnianiu w BIP KPRM podlegało ogłoszenie o wakacie oraz lista kandydatów spełniających wymogi formalne, z kolei informacja o wyniku naboru była udostępniana na wniosek. Nowa ustawa stanowi, że w miejscu powszechnie dostępnym w siedzibie urzędu oraz w BIP (KPRM oraz urzędu prowadzącego nabór) publikowane jest ogłoszenie o wakacie oraz informacja o wyniku naboru, a lista kandydatów spełniających wymogi formalne jest udostępniana na wniosek. Skrócono też termin składania dokumentów w przypadku zatrudnienia na zastępstwo - z 10 do 5 dni (art. 28). Ogłoszenie o naborze powinno zawierać - nazwę i adres urzędu, określenie stanowiska pracy, wymagania związane ze stanowiskiem pracy - zgodnie z opisem danego stanowiska (ze wskazaniem, które z nich są niezbędne, a które dodatkowe), zakres zadań wykonywanych na stanowisku pracy, wskazanie wymaganych dokumentów oraz miejsce i termin składania dokumentów. $\mathrm{Z}$ osobą po raz pierwszy podejmującą pracę w służbie cywilnej zawierana jest umowa o pracę na czas określony - 12 miesięcy, z możliwością jej rozwiązania z dwutygodniowym wypowiedzeniem (są jednak pewne odstępstwa określone w ustawie; art. 35). Osobę taką obowiązuje również służba przygotowawcza, która trwać będzie nie dłużej niż 4 miesiące, a kończy się nie później niż z upływem 8 miesięcy od podjęcia pracy (art. 36). Dyrektor generalny urzędu, kierujący pracownika do odbycia służby przygotowawczej określa jej zakres i czas trwania na podstawie opinii osoby kierującej komórką organizacyjną, w której pracownik jest zatrudniony. W pewnych przypadkach dyrektor generalny może zwolnić pracownika z obowiązku odbycia służby przygotowawczej (np. absolwentów KSAP), ale nie oznacza to zwolnienia z egzaminu kończącego tę służbę.

Osoba zatrudniona po raz pierwszy w służbie cywilnej na podstawie umowy o pracę na czas określony podlega pierwszej ocenie w służbie cywilnej, z wyłączeniem absolwentów KSAP, którzy złożyli wnioski o mia- 
nowanie w służbie cywilnej (art. 37). Ocena ta dokonywana jest nie wcześniej niż po upływie 8 miesięcy od nawiązania stosunku pracy i nie później niż miesiąc przed upływem okresu, na który zawarta została umowa. W ramach pierwszej oceny pracownika służby cywilnej uwzględnia się - postawę, zaangażowanie, postępy w pracy, relacje ze współpracownikami i terminowość wykonywania zadań, a także wynik egzaminu ze służby przygotowawczej oraz sporządzone przez ocenianego pracownika sprawozdanie dotyczące zadań realizowanych w trakcie pracy ${ }^{10}$. W przypadku przyznania oceny pozytywnej - kierownik komórki organizacyjnej, w której zatrudniony jest oceniany pracownik, wnioskuje do dyrektora generalnego urzędu o zawarcie umowy o pracę na czas nieokreślony. W przypadku oceny negatywnej - o niezawieranie takiej umowy albo o zawarcie umowy o pracę na czas określony.

Zmianą w stosunku do wcześniejszych przepisów jest rozszerzenie kwalifikacji osób ubiegających się o mianowanie, a dotyczy to nowych umiejętności językowych (udokumentowanych na określonym poziomie), wykraczających poza znajomość języków roboczych UE. Zatem o uzyskanie mianowania w służbie cywilnej może ubiegać się osoba, która jest pracownikiem służby cywilnej, posiada tytuł zawodowy magistra lub równorzędny, ma co najmniej 3-letni staż pracy w służbie cywilnej lub uzyskała zgodę dyrektora generalnego urzędu na przystąpienie do postępowania kwalifikacyjnego przed upływem tego terminu - jednak nie wcześniej niż po upływie dwóch lat od nawiązania stosunku pracy w służbie cywilnej, zna co najmniej jeden język obcy spośród języków roboczych UE lub jeden z następujących języków obcych: arabski, białoruski, chiński, islandzki, japoński, norweski, rosyjski, ukraiński oraz jest żołnierzem rezerwy lub nie podlega powszechnemu obowiązkowi obrony (art. 40). Dyrektor generalny właściwego urzędu potwierdza powyższe kwalifikacje, a także spełnienie następujących warunków u kandydata - obywatelstwo polskie, korzystanie z pełni praw publicznych, niekaralność za umyślne przestępstwo lub umyślne przestępstwo skarbowe. Postępowanie kwalifikacyjne pracowników ubiegających się o mianowanie prowadzi tak jak to było dotychczas Krajowa Szkoła Administracji Publicznej (art. 43). W toku postępowania kwalifikacyjnego do końca

10 Rozporządzenie Prezesa Rady Ministrów z dnia 15 czerwca 2009 r. w sprawie szczegółowych warunków i sposobu dokonywania pierwszej oceny w służbie cywilnej, Dz. U. Nr 94, poz. 772. 
2009 roku weryfikowało się wiedzę, umiejętności i predyspozycje kierownicze ${ }^{11}$. Przepisy nowej ustawy o służbie cywilnej dotyczące postępowania kwalifikacyjnego, którego podstawą jest wiedza i umiejętności - weszły w życie z dniem 1 stycznia 2010 roku $^{12}$. Do tego czasu postępowanie kwalifikacyjne prowadzone było na dotychczasowych zasadach, określonych ustawą z 24 sierpnia 2006 r. o służbie cywilnej. Mianowań w ramach limitu określonego w ustawie budżetowej dokonuje Szef Służby Cywilnej (wcześniej Prezes Rady Ministrów) w imieniu Rzeczypospolitej Polskiej. Akty mianowania otrzymują pracownicy służby cywilnej, którzy z wynikiem pozytywnym ukończyli postępowanie kwalifikacyjne w służbie cywilnej oraz uzyskali miejsce uprawniające do mianowania. Szef Służby Cywilnej mianuje także absolwentów Krajowej Szkoły Administracji Publicznej, którzy w danym roku złożyli wnioski o mianowanie. Urzędnik służby cywilnej składa ślubowanie i potwierdza je podpisem $\mathrm{w}$ akcie mianowania. $\mathrm{Z}$ dniem mianowania stosunek pracy na podstawie umowy o pracę przekształca się w stosunek pracy na podstawie mianowania. Zmianie ulega podstawa zatrudnienia, a inne elementy dotychczasowego stosunku pracy nie ulegają zmianie (np. miejsce pracy, stanowisko, wynagrodzenie zasadnicze). Natomiast dyrektor generalny urzędu przyznaje urzędnikowi służby cywilnej w terminie 7 dni od dnia mianowania - najniższy stopień służbowy, przysługujący od dnia mianowania (art. 51 ust. 1). W związku z posiadanym stopniem służbowym, urzędnik służby cywilnej otrzymuje dodatek służby cywilnej. Status urzędnika służby cywilnej charakteryzuje stabilniejsza forma stosunku pracy, niż w przypadku pracownika służby cywilnej (ograniczony katalog możliwości rozwiązania stosunku pracy), dodatkowe uprawnienia (dodatek służby cywilnej, dodatkowy urlop wypoczynkowy), zwiększona dyspozycyjność oraz obowiązki i ograniczenia. Te ostatnie to zwłaszcza - mniej korzystny sposób rekompensaty za pracę w godzinach nadliczbowych (art. 97, ust. 7 i 8), zakaz tworzenia i uczestniczenia w partiach politycznych (art. 78 ust. 5 ) czy

11 Rozporządzenie Prezesa Rady Ministrów z dnia 24 stycznia 2007 r. w sprawie sposobu przeprowadzenia postępowania kwalifikacyjnego w służbie cywilnej, Dz. U. Nr 13, poz. 82; Rozporządzenie Prezesa Rady Ministrów z dnia 27 grudnia 2007 r. zmieniające rozporządzenie w sprawie sposobu przeprowadzania postępowania kwalifikacyjnego w służbie cywilnej, Dz. U. Nr 249, poz. 1857.

12 Por. Rozporządzenie Prezesa Rady Ministrów z dnia 16 grudnia 2009 r. w sprawie sposobu przeprowadzania postępowania kwalifikacyjnego w służbie cywilnej, Dz. U. Nr 218, poz. 1695. 
obowiązek składania oświadczeń majątkowych, bez względu na zajmowane stanowisko pracy (art. 10 ustawy z dnia 21 sierpnia 1997 r. o ograniczeniu prowadzenia działalności gospodarczej przez osoby pełniące funkcje publiczne, Dz. U. 2006, Nr 216, poz. 1584).

Modyfikacji uległ również system wynagrodzeń członków korpusu służby cywilnej, a nowe regulacje obowiązują od dnia 1 stycznia 2010 $\mathrm{roku}^{13}$. W porównaniu do obowiązującego wcześniej rozporządzenia ${ }^{14}$, zmiany dotyczą m.in. zmniejszenia rozpiętości przedziałów mnożników kwoty bazowej, służących do ustalenia wynagrodzeń zasadniczych członków korpusu służby cywilnej, wynikających z obowiązujących przepisów prawnych - wymagań w zakresie stanowisk i kwalifikacji, zmniejszenia progresji wzrostu mnożników kwoty bazowej służących do ustalenia dodatków służby cywilnej dla urzędników służby cywilnej, posiadających VI stopień służbowy i stopnie wyższe. Przedziały mnożników pozwoliły na wyraźne przestawienie hierarchii wynagrodzeń w poszczególnych grupach stanowisk i urzędów oraz stworzono możliwość bardziej elastycznego kształtowania wynagrodzeń, zwłaszcza w grupach stanowisk - wyższych, średniego szczebla zarządzania, koordynujących i samodzielnych. Nowe regulacje dotyczą także zasad ustalania prawa do dodatku za wieloletnią pracę w służbie cywilnej oraz nagrody jubileuszowej.

Podążając naprzeciw standardom administracyjnym $\mathrm{w}$ instytucjach UE, ustawa o służbie cywilnej wprowadziła obowiązkowe oceny okresowe dla wszystkich członków korpusu służby cywilnej, a nie tylko - jak to było poprzednio - dla urzędników służby cywilnej (art. 81). Zatem objęto oceną okresową również pracowników służby cywilnej, zatrudnionych na podstawie umowy o pracę, na czas nieokreślony. Ocena okresowa obejmuje wykonywanie obowiązków służbowych, wynikających z opisu stanowiska pracy, a sporządzana ma być co 24 miesiące. Powinna zawierać wnioski dotyczące indywidualnego programu rozwoju zawodowego członka korpusu służby cywilnej. Urzędnik służby cywilnej, który otrzy-

13 Por. Rozporządzenie Prezesa Rady Ministrów z dnia 9 grudnia 2009 r. w sprawie określenia stanowisk urzędniczych, wymaganych kwalifikacji zawodowych, stopni służbowych urzędników służby cywilnej, mnożników do ustalania wynagrodzenia oraz szczegółowych zasad ustalania i wypłacania innych świadczeń przysługujących członkom korpusu służby cywilnej, Dz. U. Nr 211, poz. 1630.

14 Rozporządzenie Prezesa Rady Ministrów z dnia 16 stycznia 2007 r., Dz. U. $\mathrm{Nr} 12$, poz.79. 
mał dwie kolejne - następujące po sobie oceny okresowe, na jednym z dwóch najwyższych poziomów w skali ocen, obligatoryjnie otrzymuje kolejny stopień służbowy w terminie 30 dni od dnia zapoznania się z oceną. Nowością jest również to, że w sposób wyczerpujący wskazano okoliczności, w których bezpośredni przełożony może zmienić termin sporządzenia oceny - określono sytuację, w której następuje obowiązkowe przedłużenie terminu sporządzenia oceny. Warto nadmienić, że istotne zmiany w przeprowadzaniu ocen okresowych członka korpusu służby cywilnej zostały wprowadzone na poziomie aktu wykonawczego i obowiązują od dnia 3 czerwca 2009 roku $^{15}$. W obowiązującym rozporządzeniu opracowano nową metodologię sporządzania ocen okresowych poprzez wprowadzenie punktowej skali ocen, a także przedstawiono odrębne kryteria oceny i arkuszy ocen dla osób zajmujących wyższe stanowiska w służbie cywilnej oraz stanowiska kierowników urzędów, które są stanowiskami pracy w służbie cywilnej (załącznik nr 3 oraz Arkusz „B”). Pozostali członkowie korpusu służby cywilnej (zatrudnieni na stanowisku pracy niebędącym wyższym stanowiskiem w służbie cywilnej, ani stanowiskiem kierownika urzędu, które jest stanowiskiem pracy w służbie cywilnej są również poddani odrębnej ocenie okresowej (załącznik nr 1 i 2, Arkusz „A").

Warto też zwrócić uwagę, że nowa ustawa o służbie cywilnej dała możliwość bezpośrednim przełożonym na ustalenie indywidualnego programu rozwoju zawodowego wszystkim członkom korpusu służby cywilnej - z wyjątkiem dyrektorów generalnych urzędów (art. 108). Program ten stanowi podstawę do kierowania członków korpusu służby cywilnej na szkolenia. Indywidualny program rozwoju zawodowego uwzględnia w szczególności - wnioski zawarte w ocenie okresowej, planowany awans stanowiskowy, awans finansowy, a także plany i możliwości rozwoju zawodowego członka korpusu służby cywilnej oraz potrzeby i możliwości urzędu w zakresie zatrudnienia. Program ma być akceptowany przez osobę kierującą komórką organizacyjną i zatwierdzany przez dyrektora generalnego urzędu. Szkolenia i rozwój zawodowy członków służby cywilnej na szczeblu centralnym są planowane (przy wsparciu KSAP), organizowane i nadzorowane przez Szefa Służby Cywilnej (art. 107). Celem szkoleń jest

15 Rozporządzenie Prezesa Rady Ministrów z dnia 8 maja 2009 roku w sprawie warunków i sposobu przeprowadzania ocen okresowych członków korpusu służby cywilnej, Dz. U. Nr 74, poz. 633. 
nabycie umiejętności pracy w grupie, koordynacji pracy w urzędzie i administracji, upowszechnianie jednolitych standardów pracy oraz przygotowanie do partnerstwa europejskiego ${ }^{16}$. Plan szkoleń centralnych jest ustalany co roku, a w szczególności zawiera - priorytety szkoleniowe wobec członków korpusu służby cywilnej, rodzaje szkoleń mające duże znaczenie w danym roku oraz inne zalecenia i informacje dla osób organizujących i nadzorujących szkolenia w służbie cywilnej. Ustawa również przewiduje, inne rodzaje szkoleń - szkolenia powszechne, szkolenia w ramach indywidualnego programu rozwoju zawodowego członka korpusu służby cywilnej oraz szkolenia specjalistyczne (art. 106).

Kolejnym elementem zmian, znanym również administracji instytucji europejskiej jest realizowanie tzw. planów strategicznych ${ }^{17}$. Ustawa o służbie cywilnej nałożyła na Szefa Służby Cywilnej obowiązek opracowania i wdrożenia strategii zarządzania zasobami ludzkimi w służbie cywilnej (art. 15, ustęp 2). Strategia musi zawierać opis aktualnego stanu służby cywilnej, tzw. „diagnozę służby cywilnej” (procedury - rekrutacji, ocen pracowniczych, rozwoju kariery oraz rozwoju umiejętności menedżerskich), określenie celów strategicznych i systemu ich realizacji oraz wskazanie ram finansowych. Ponadto strategia powinna zawierać takie elementy jak - wizja i misja służby cywilnej, a także określenie obszarów wdrożenia strategii. Misją służby cywilnej jest zapewnienie zawodowego, rzetelnego, bezstronnego i politycznie neutralnego wykonywania zadań państwa oraz ciagłości funkcjonowania instytucji państwa, niezależnie od bieżącej sytuacji politycznej i zmian rządów. Zasada profesjonalizmu oznacza, że praca w służbie cywilnej jest stałym źródłem utrzymania pracowników zatrudnionych w oparciu o merytoryczne kryteria, dysponujących wiedzą i umiejętnościami zapewniającymi prawidłowe wykonywanie swoich obowiązków służbowych. Natomiast zasada rzetelności oznacza wykonywanie obowiązków kompetentnie, z zachowaniem terminów i w sposób ekonomicznie racjonalny. $Z$ kolei bezstronność działania członków korpusu służby cywilnej polega na równym traktowaniu wszystkich podmiotów, których dotyczą podejmowane przez nich czynności (wydawane decyzje, postanowienia, udzielane zamówienia publiczne itd.), a neutralność polityczna to podstawa w kierowaniu się normami prawa i standardami

16 www.dsc.kprm.gov.pl/strona.php?id=36\&id2=21, odczyt 19.02.2010.

17 Oświadczenie dotyczące przestrzegania ładu administracjno-regulacyjnego wydane przez Komisję Europejską, Bruksela 2007, s. 6. 
interesu publicznego (nie uleganie wpływom partii politycznych, organizacji społecznych, związków zawodowych oraz wszelkim grupom nacisku). Szef Służby Cywilnej określa również standardy zarządzania zasobami ludzkimi w służbie cywilnej. W związku z tym w budżecie państwa ma zostać utworzona rezerwa celowa na „modernizacje” służby cywilnej. Dysponować ją będzie Szef Kancelarii Prezesa Rady Ministrów, na wniosek Szefa Służby Cywilnej. Na koniec zmian, jakie czekają służbę cywilną, warto wspomnieć, że po raz pierwszy od czasu przywrócenia w Polsce służby cywilnej, ustawodawca zobowiązał Prezesa Rady Ministrów do wydania zarządzenia zawierającego wytyczne w zakresie przestrzegania zasad służby cywilnej oraz określającego zasady etyki korpusu służby cywilnej. Akt ten ma zastapić Kodeks Etyki Służby Cywilnej.

Ustawa o służbie cywilnej z 2008 roku wprowadziła szereg instrumentów, które mają zapewnić spójność podejmowanych działań, a w konsekwencji stabilność w zarządzaniu zasobami ludzkimi. Do instrumentów tych można zaliczyć m.in. - strategię i programy zarządzania zasobami ludzkimi w służbie cywilnej i w urzędzie, wytyczne odnośnie wprowadzania zasad służby cywilnej, zasady etyki korpusu oraz instrumenty umożliwiające Szefowi Służby Cywilnej - kontrolowanie, monitorowanie i nadzorowanie zarządzania zasobami ludzkimi, a także jego współpraca z dyrektorami generalnymi urzędów i możliwość wykorzystania środków rezerwy budżetowej na modernizację służby cywilnej. Warto podkreślić jeszcze raz, że nowe instrumenty monitorowania naboru na wyższe stanowiska w służbie cywilnej (kierowanie przez Radę Służby Cywilnej i Szefa Służby Cywilnej przedstawicieli, w celu obserwacji przebiegu procesu naboru czy rekomendacje Szefa Służby Cywilnej dotyczące przeprowadzenia naboru) tworzą wiarygodne podstawy rekrutacji. Poza tym wspomniany już nowy system ocen okresowych to jedno z podstawowych narzędzi zarządzania zasobami ludzkimi i stąd jest tak ważny dla poprawy efektywności pracy, podejmowania decyzji kadrowych (awanse, przeniesienia), planowania, zatrudniania, ustalania ścieżek kariery pracowników oraz kształtowania wysokości wynagrodzeń. Ocena na poziomie indywidualnym ma na celu weryfikację wykonywania obowiązków i wyznaczanie kierunków rozwoju zawodowego, a więc motywowanie pracowników do dalszego doskonalenia. Patrząc szerzej na ten problem - dla organizacji, system ocen powinien wpłynąć na jej efektywność i jakość w funkcjonowaniu. Dostrzeżono walory ocen okresowych w pracy urzędników instytucji Unii Europejskiej. Od roku 2004 administratorzy, jak i asystenci wszystkich 
stopni są poddawani ocenie okresowej ${ }^{18}$. Procedury ocen okresowych są dostosowane do wagi stanowiska. Inaczej oceniany jest zwykły personel urzędniczy, średni szczebel zarządzania (szefowie wydziałów) i wyżsi urzędnicy. Niemniej ocena taka ma sprowadzać się do trzech stałych celów - awansowania urzędnika, jego mobilności i zapobiegania działaniom korupcyjnym. Procedura oceny czy procedura promocji powstaja w oparciu o opisy stanowisk pracy, powstające z kolei na bazie strategicznego planowania. Jak można zauważyć, polska administracja w tym kontekście zbliżyła się również do standardów europejskich. W ogóle należy podkreślić, że obecnie dużym wyzwaniem jest przygotowanie służby cywilnej do wykonywania zadań w trakcie sprawowania przez Polskę przewodnictwa w Radzie Unii Europejskiej. Stąd szkolenia i inne formy podnoszenia kompetencji czy korzystanie $\mathrm{z}$ europejskich wzorców są szansą na podniesienie walorów funkcjonowania służby cywil$n j^{19}$. Nie bez powodów uważa się, że wspólnie od urzędników z Brukseli, jak też tych - krajowych zależy funkcjonowanie europejskiej deus ex machina ${ }^{20}$.

\section{Summary}

The civil service in Poland lacks legal and institutional continuity. Four laws regarding the civil service have been enacted over the past twelve years which have made different provisions concerning, for example, the body in charge of the civil service (The Civil Service Supervisor or the Head of the Chancellery of the Prime Minister) and handling its matters (The Civil Service Office of the Chancellery of the Prime Minister), the status of higher posts (in the civil service and outside of it) and the manner of manning such posts (contests, appointments, enrollment). The act on the civil service of 2008 introduced a range of instruments to provide for consistent operations and, consequently, stability of human resource management. It should be emphasized

18 Staff Regulations of Officials of the European Communities. Conditions of employment of other servants of the European Communities, „Official Journal of the European Communities", L 56, 1968, art. 43-46.

19 W lipcu 2009 roku powstał dwumiesięcznik „Przegląd Służby Cywilnej”, wydawany przez Szefa Służby Cywilnej - szerzej www.dsc.kprm.gov.pl. Pismo wypełnia funkcje - informacyjną i edukacyjną, przedstawiając na swych łamach funkcjonowanie polskiej służby cywilnej i problematykę związaną z tą grupą zawodową. Stąd też pismo jest kierowane do szerokiego czytelnika, zainteresowanego działalnością służby cywilnej.

20 Europa urzędników, pod red. Z. Brodeckiego, Warszawa 2009, s. 37. 
that at present the challenge concerning the civil service is to prepare it for the tasks to be fulfilled while Poland holds the presidency of the Council of the European Union. Providing training and applying various methods to develop civil servants' competence as well as adopting European models are a chance to increase the quality of civil service operations. 